Potts A. Writing Sound and Radical Fiction: the Abyssal Space of Writing, Reading and Listening. New Writing: The International Journal for the Practice and Theory of Creative Writing 2017, 14(1), 117-126.

DOI link

http://dx.doi.org/10.1080/14790726.2016.1250783

ePrints link

http://eprint.ncl.ac.uk/pub details2.aspx?pub id=227078

Date deposited

$08 / 02 / 2018$

Copyright

This is an Accepted Manuscript of an article published by Taylor \& Francis in New Writing on 03/11/2016, available online: http://dx.doi.org/10.1080/14790726.2016.1250783

\title{
Licence
}

This work is licensed under a

Creative Commons Attribution-NonCommercial-NoDerivatives 4.0 International licence

$$
\text { (c) } \underset{\mathrm{BY}}{(} \mathrm{NC}_{\mathrm{ND}}
$$




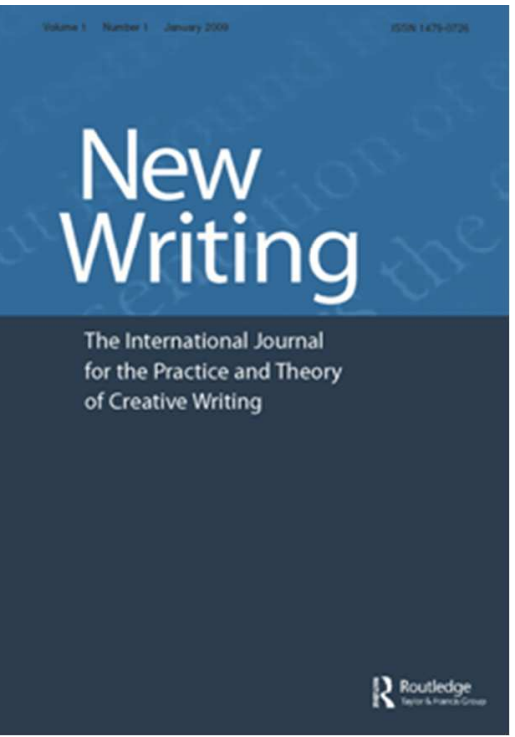

\section{Writing Sound and Radical Fiction: The Abyssal Space of Writing, Reading and Listening}

\begin{tabular}{|r|l|}
\hline Journal: & $\begin{array}{l}\text { New Writing: The International Journal for the Practice and Theory of } \\
\text { Creative Writing }\end{array}$ \\
\hline Manuscript ID & NEW-1377.R1 \\
\hline Manuscript Type: & Paper \\
\hline Keywords: & Critical reading, Experimentation, Poetry, Blanchot, Cascella, Sound \\
\hline Abstract: & $\begin{array}{l}\text { This article aims to establish a connection between Daniela Cascella's } \\
\text { writing sound and Maurice Blanchot's radical fiction. It will show how } \\
\text { Cascella's interest in the relationship between sound and writing pulls her } \\
\text { toward a similar abyssal space as the one Blanchot arrives at in his critical } \\
\text { essays and own works of fiction. By firstly distinguishing her work, by } \\
\text { emphasising its poetic power, from certain trends in sound studies, this } \\
\text { essay will read Cascella alongside the writing of Blanchot. It will be shown } \\
\text { how both Cascella and Blanchot's writing circles a vanishing point in which } \\
\text { the inaugural moment of writing slowly dissipates. The significance of } \\
\text { reading will then be explored as a prolongation of this dispossessing } \\
\text { temporality of writing. Importantly, then, this article is not trying to say } \\
\text { something about the ontological dimension of sound. The commonality } \\
\text { drawn between these two authors will be positioned according to the } \\
\text { strangeness of writing. }\end{array}$ \\
\hline \hline
\end{tabular}




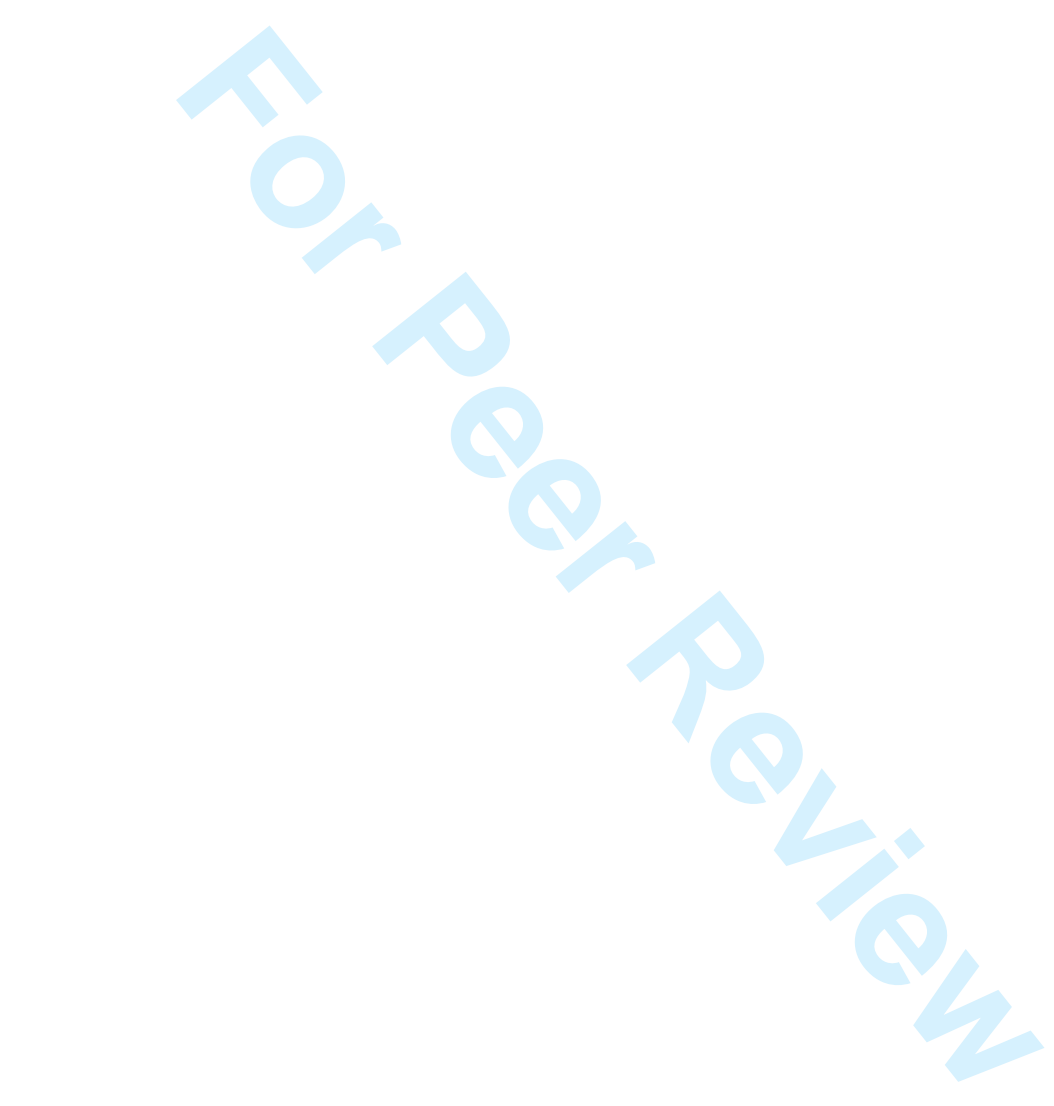

Page 1 of 10

Page 1 of 10

Page 1 of 10
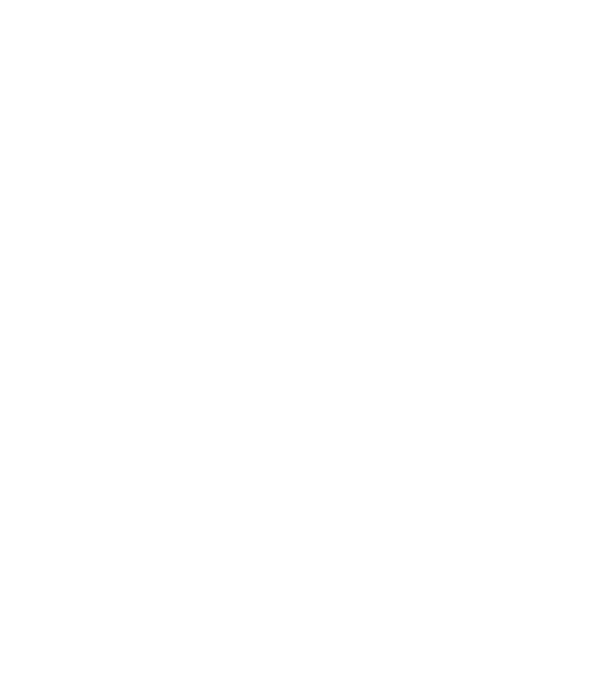
(1)
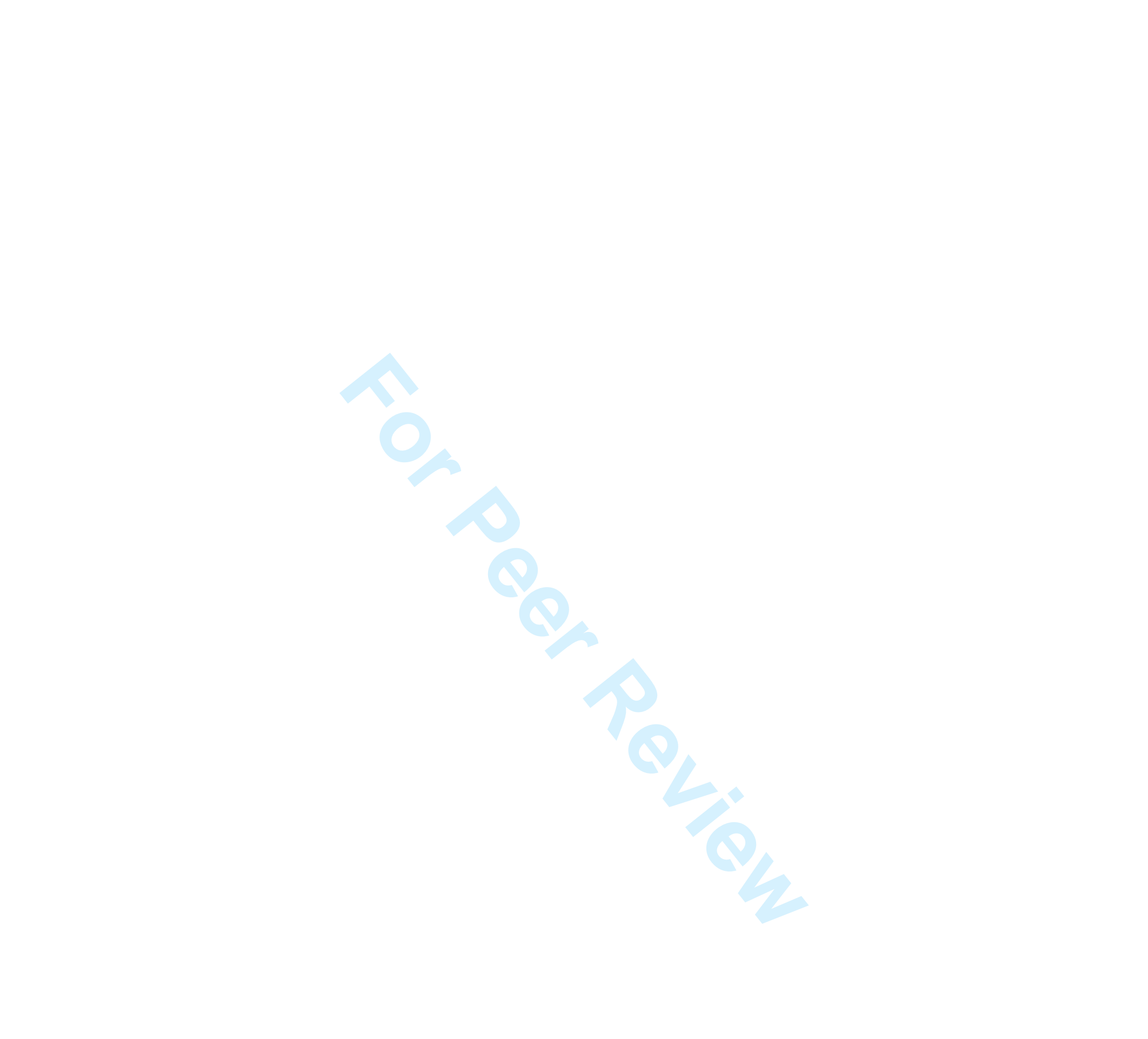


\title{
Writing Sound and Radical Fiction: The Abyssal Space of Writing, Reading and Listening
}

\begin{abstract}
This article aims to establish a connection between Daniela Cascella's writing sound and Maurice Blanchot's radical fiction. It will show how Cascella's interest in the relationship between sound and writing pulls her toward a similar abyssal space as the one Blanchot arrives at in his critical essays and own works of fiction. By firstly distinguishing her work, by emphasising its poetic power, from certain trends in sound studies, this essay will read Cascella alongside the writing of Blanchot. It will be shown how both Cascella and Blanchot's writing circles a vanishing point in which the inaugural moment of writing slowly dissipates. The significance of reading will then be explored as a prolongation of this dispossessing temporality of writing. Importantly, then, this article is not trying to say something about the ontological dimension of sound. The commonality drawn between these two authors will be positioned according to the strangeness of writing.
\end{abstract}

Key words: Maurice Blanchot; Daniela Cascella; sound; writing; listening; reading

'... as if from the outer edge of a buried age, I begin to write'.

- Daniela Cascella

\section{Writing sound and radical fiction}

Daniela Cascella's writing responds to experiences that are not given to meaning easily. On the surface, this work belongs to the growing field of sound studies as an articulation of what she perceives as the ethereal quality of sound. This is the most uninteresting dimension of her work as it relies, even if only implicitly, on those sense-related prejudices - a privileging of the oral over the visual - that Jonathan Sterne cautions us against $(2003,18)$. Yet beneath the surface, Cascella is responding to a region without privilege from a position that refuses orientation. Similar to how Jean-Luc Nancy describes the consanguinity of the arts - 'they never cease to pass into each other, to present themselves in place of one another' $(1993,389)$ - Cascella cannot write about sound without it passing into references to literature, poetry, music and most importantly the very act of writing itself. Nancy argues this type of passage is allowed because 'none of them [the arts] represent anything' but instead share a 'presence without essence' allowing one to pass into the other as mere instances of 'multiple singularities' (1993, 389). Cascella's writing seems to share this view; the non-hierarchical interchangeability is a manifest condition of multiple singularities to which her writing responds. It is at this point where Cascella's writing is most interesting as it becomes radically reflexive; she cannot write about these phenomena without writing about writing itself. In this regard, her work becomes the very space of alterity that is opened up by the question of the possibility of writing as it responds to the sonorous and the literary.

With the reflexive nature of her writing Cascella gravitates to a space similar to what Jeff Fort refers to as 'radical fiction' $(2014,10)$. This radical fiction bares a gravitational pull that has drawn the gaze of a number of twentieth-century writers who are occupied by, rather than occupy, the literary space - of which Maurice Blanchot is a seminal example. This type 
of writing is, Fort explains, characterised by a 'radical autobiography' as it is a 'writing so intimate that it cannot help but mark the "self" whose possibility it scatters into the alienating forms that constitute it' $(2014,10)$. What is at stake in this writing is the self as it is placed between language and life; a self responding to experience as it exceeds 'noetico-noematic correlative structures of phenomenology' (Critchley 1997, 73). Similar to these authors, Cascella writes about experience as it turns towards the impossibility of knowledge and representation. What on the surface might seem like a preservation of life, a quirky autobiography positioned around sonic and literary encounters, is slowly swallowed by the limit of experience.

Cascella calls her work 'writing sound' $(2012,71)$. The coupling of these terms indicates that this is not simply writing that is about sound but is an entry point for a writing that is not tied to origin or representation; writing as a fabulation that on the one had is evoking an acoustic dimension but on the other is a response to the 'memorial trace' of sound, the 'reminiscence that is convoked' (Bonnet 2016, 30) as an echoic memory. The multidimensionality of sensorium that congeals to constitute memory means that these memories are not simply sonic. Described as the most 'literary listener' $(2015$, i) by Craig Dworkin, these memories are as literary as they are sonorous for Cascella and characterised as they are by the absence-as-presence of the trace, their evocation is a strangely impossible one - much like the strangeness at the heart of Blanchot's communications. The focus of such writing is what exists on the hither side of rationalisation occupied, as it is, by what refuses to be assimilated. Sound and it's passing back and forth between literary, poetic and visual referents, is the inaugural moment in which writing becomes reflexive for Cascella. These entry points draw Cascella to a world in its appearing and disappearing and crucially toward literature's great refusal as it is understood by the authors of radical fiction and particularly Blanchot.

The general aim of this paper is to frame Cascella as one such surveyor. By firstly distinguishing her work, by emphasising its poetic power, from certain trends in sound studies, this essay will then read Cascella alongside that of Blanchot. It will be shown how both Cascella and Blanchot's writing circles a vanishing point in which the inaugural moment of writing slowly dissipates. The significance of reading will then be explored as a prolongation of this dispossessing temporality of writing. Importantly, then, this essay is not trying to say something about the ontological dimension of sound. The commonality drawn between these two authors will be positioned according to the strangeness of writing.

\section{Epistemological myopia or poetics?}

In a recent paper called 'Exit Immersion', Will Schrimshaw criticises the 'new orthodoxy' of immersion within sound studies. Among his multi-faceted critique is the suggestion that this experiential quality - which emphasises embodiment as being 'bathed in sound' - opposes itself to rationalisation and critical thinking in a kind of epistemological myopia: 'an unduly conservative limitation of the scope of humanity's epistemological capabilities' (Schrimshaw $2016,156)$. His concern is the way in which an auditory phenomenology has elevated listening as a way of addressing a supposedly ocularcentric metaphysics. The result is a listening hegemony that describes sound as ephemeral and capable of overcoming the rigidity that results from vision and its conceptual/metaphysical accompaniments. At the centre of this hegemony is a subject who regards sound at the expense of sonic practice and its epistemic value. What is really at stake for Schrimshaw, however, is a matter of courage daring to say something about sound itself beyond the phenomenological encounter otherwise one falls prey to Quentin Meillassoux's correlationism critique of phenomenology.

While Cascella does not address the contemporary significance of sonic practice and while she writes from this radical autobiographical position, this does not mean she is 
compatible with phenomenology as understood by Schrimshaw or for that matter typical of sound studies. Meillassoux defines correlation as 'the idea according to which we only ever have access to the correlation between thinking and being, and never to either term considered apart from the other' $(2009,5)$. As Schrimshaw explains, there are two principle components that constitute the constraining relationship of correlation: 'phenomenology and the linguistic turn' $(2016,164)$. This means that correlationism does not just refer to the likes of Salomé Voegelin who writes, when listening to Japanese noise artists Merzbow, 'I [...] merge with the thinging of noise,' thus becoming a 'noisy thing myself' as the 'dense ephemerality of sound as itself' $(2010,68)$. It also extends to the likes of Cascella for whom sound is nothing without our relation to it: 'I have a habit with listening. When I hear a record or sound piece before I hear it, I anticipate and deliberately infiltrate my experience and memory of it' $(2015,9)$. However, although unquestionably a statement of correlation, this infiltration does not secure an anthropic horizon of interiority, via immersion, as it does in Voegelin's work. This infiltration is initiated through writing but Cascella's writing is fundamentally a writing of disappearance rather than revelation. In keeping with the (non)tradition of radical fiction, she belongs next to the likes of Blanchot as a writer who acknowledges writing as a kind of limit-experience where, as Gerald Bruns explains, 'the one who writes is turned inside out, evacuated, becoming something entirely other, without identity' $(2011,1)$. In other words, Cascella does not preclude the outside or the exterior, as Schrimshaw suggests the authors of immersion do, as this outside/exteriority is what turns the would-be interiority of the experiencing subject inside-out during the activity of writing.

One could, quite easily, read this dispossession as another instance of the epistemological myopia Schrimshaw cautions us against but the suggestion in this paper is that there is something more radical and poetic (in a strictly Blanchotian sense) occurring in Cascella's work. Voegelin clearly states that 'sound's ephemeral invisibility obstructs critical engagement'. Our only hope of attending to sound, for Voegelin, is through a phenomenology of sorts that describes our so-called immersion in sound's 'auditory object' (2010, xi-xii). At times, Cascella repeats this litany of ephemerality: sound is frequently described as an 'ephemeral impossibility of being captured' $(2015,4)$. But what supersedes these sorts of claims in her work is a circular activity of writing where it no longer holds as a secondary and thereby inadequate response to sound. The reflexive nature of writing takes centre stage over the supposed ontological characteristics of sound and in these moments, Cascella avoids the tired cliche that it is impossible to write about sound by choosing to write 'away from sound' $(2015,44)$. She contrasts this notion to the idea of writing 'after sound', where writing would be a secondary and inferior by-product of listening. Writing away from sound means that writing is no longer preoccupied with the burden of representation. 'As a document of sound' - as an activity of representation - 'writing fails' but free from this preoccupation, writing away from sound is, for Cascella, more like 'fabulation: a creative act, grounded on its own devices and artifices [...] it supports the ephemeral of listening, it is not tied to a permanent origin' $(2015,44)$. What this means is that her words are not concerned with representation as they 'construct and open up each experience of listening rather than being subordinated to it' and in so doing 'create another space for inhabiting sound' (Cascella 2015, 45). This 'other' space is what draws Cascella away from the likes of Voegelin and closer to those authors of radical fiction, particularly Blanchot.

In contrast to the authors of immersion/interiority and their emphasis on the proximity between the listening subject and the 'given-to-be-heard' (Bonnet 2016, 83) auditory object, writing away from sound demands that sound be kept at a distance: 'You must not listen closer, you must listen distant, far away, distracted' (Cascella 2015, 22). Sound, for Cascella, cannot be interiorised or framed via narratives of being bathed and consumed by the sonorous. The audibility of sound is made manifest by a distance much like François Bonnet's 
idea of the sonic trace. Distinguishing between the sonorous and the audible - the relationship between the two being a process of domestication of the former into the latter Bonnet suggests the trace is what makes the sonorous audible: 'A sound, in order to be audible, must leave a trace' $(2016,31)$. Echo, resonance and reverberation all embody the trace both acoustically and figuratively; they symbolise the physical trace of sound as well its memorial trace as echoic memory. In short, the trace is what provides sound with a certain signifying traction that allows the sonorous field to be heard but the trace itself is nothing. Thus, what conditions the encounter with sound is a passing trace that is, as Jacques Derrida originally explains when discussing différance and the trace, 'incompatible with the concept of retention [...] one cannot think the trace on the basis of the present' $(1982,21)$. Cascella's writing is a response to the traces of sounds; that is to say, her writing is attentive more to the absences at the centre of the audible than any kind of interiorised/immersive depiction of sound.

In other words, it can be said that what Cascella is responding to in her writing is the void against which the audible is demarcated in much the same way the poet, as Blanchot understand him/her ${ }^{1}$, responds to that neutral region of singularities left behind by the communicative/audible function of language. There is, in Blanchot's work, always two orders of writing: naming and response ('naming the possible, responding to the impossible' (Blanchot 1999, 48)). Naming is always the formulation of an answer - it gives us the world and conceptualises the unknown as a confrontation with meaning. Response, on the other hand, does not appease the question at hand as it does not formulate an appropriate answer. It is a response to the unknown as a region of anarchic refusal, a foreignness not simply estranged or antithetical but other to the system of differentiation entirely. A response to the impossible does not illuminate it but simply answers to it, 'saying in responding' (Blanchot 1999, 48). For Blanchot, the point of articulating these two languages is to remind us that possibility is not the only dimension of existence and naming/representation is not the only function of language. The poet, and the authors of radical fiction, are reminders of this; their use of language exceeds possibility resulting in something uncanny and strange as words are no longer subject to their conceptual function. While not poetic in a Mallarméan sense of the term, by responding to the absence that constitutes the trace, rather than just the resulting audibility of the trace, Cascella addresses the ephemerality of sound in a poetic manner; instead of looking for answers her work 'echoes questions with questions, riddles with riddles, it adds complexity to complexity' $(2012,73)$. Her writing is a fragmented/non-linear collection of 'approximations of nothing' $(2015,43)$ made in response to the vanishing point of sound. Her writing, then, does not mark the inadequacy of critical discourse when it comes to sound (although on the surface it might seem so) but is on the hither side of such dialectical differences as a response to the non-identical (trace). It is in these moments that we can understand her work as an attempt to expose us to an inhabitation of sound from a poetic region; this is where she aligns herself with Blanchot and the vanishing point of writing itself.

The vanishing point: how to write in front of sound?

How is it possible to write in proximity of the trace as absence rather than its resulting audibility? Cascella phrases this question in her own way when she asks: 'how to write in front of sound?' $(2015,27)$. In front because this type of writing is not interested in the audible world but the trace (the nature of which is absence) that is the primordial condition of the audible. The trace is, according to Bonnet, 'the divergence between sound and what remains of it' $(2016,32)$, what is left of the sonorous when we take away the audible. Writing, for Cascella, is intimately bound with the trace because of the distance between writing and sound, a distance that delimits the ephemerality of the audible: 'As I listen to 
sounds and then set out to write, I become more and more aware of my distance from them. My words cannot capture them: they let them go astray, dissolve' (Cascella 2012, 72). Sounds are displaced from their origins as she begins the process of writing. Quite literally, the audible is not present when one writes about sound: it resounds only as a memory. What is more - and here we come to the crucial intersection between Cascella and Blanchot's thought - writing itself becomes the trace of the audible trace: ' I think of Writing Sound as the trace of the experience that makes it. It conveys the sense of shaping, step by step along with the journey of listening and the writing $I$, words into places at once familiar and strange' (Cascella 2012, 74). This is what it means to write in front of sound. It is the paradox of writing sound and it mirrors that of radical fiction. What Blanchot says about Søren Kierkegaard - 'he is a writer because this fundamental anxiety has revealed itself to him, and at the same time it reveals itself to him because he is a writer' $(2001,4)$ - is also true of Cascella: she is a writer because the trace of sound has revealed itself to her and at the same time it reveals itself to her because she is a writer of sound.

This brings us to the intimacy, related to dispossession, that is characteristic of both Cascella and Blanchot's writing. Fort defines radical fiction as an intimacy so intense it scatters the author who writes it. But what is the author intimate with? The answer is writing. The author of radical fiction is intimately bound up with their writing to such a degree that their very subjectivity is constituted by writing itself. This is how Blanchot understands Marcel Proust. It was Proust's intention to 'harvest' the content of the book from the 'unadulterated essence of my [his] entire life' (Blanchot 2003, 20). However, it is not as straightforward as suggesting that the narrative can be read as an autobiography. Proust pulls us to the paradox of writing where the events in question only take on significance because of their narration. For Proust, writing is not a report of an event that took place - out of which we might safely say writing begins - rather writing constitutes the event itself; events that are thought to make narration possible only become real as an event because of the narration. It is an odd twist 'where what is meant to be posterior, [...] now becomes anterior' (Large 2004, 80). Writing sound, as a writing away from sound that constructs and opens up the experience of sound itself, is what signifies a similar intimacy in Cascella's work. She is interested in the passage from the sonic experience into writing and back again - 'the shift from real to fiction and the sliding back from fiction to real' - something that, as she goes onto explain, 'occurs every time we are confronted with aural memories as escapes out of fixity' (Cascella 2015, 34). Yet unlike Proust, and closer to Blanchot, this folding of writing back onto the real is what instigates the vanishing point of the experience. What begins as a response to the trace that constitutes the ephemerality of sound slowly becomes the very condition of the trace; for Cascella writing constitutes the sonic encounter as one of distance and imperceptibility. For both writing sound and radical fiction writing secures nothing other than an amplification of the imperceptible. This also means, then, that writing is the experience of alienation as subjectivity is turned inside-out.

In the opening exchange of L'Entretien infini Blanchot draws the reader toward this fundamental paradox that belongs to this type of writing via the phenomenon of weariness. The exchange is between two unnamed characters engaged in a strange conversation made all the more unusual because of the state of weariness they find themselves in. However, weariness is more than just a state of extreme tiredness for the characters; it is a limitexperience where the very capacity to experience, to conceive of the world phenomenologically, has broken down. Although weariness is common to both of the speakers it is not enough to bring them together precisely because their very capacity to engage as a subject is no longer present: 'As if weariness were to hold up to us the preeminent form of truth, the one we have pursued without pause all our lives, but that we necessarily miss on the day it offers itself, precisely because we are too weary' (Blanchot 1999, xiii). 
Weariness is always missed by the person who is too weary. In other words, one is only weary when one loses their subjective capacity to be weary. In the experience of weariness, fatigue and exhaustion endure over any sense of selfhood as our engagement with the temporal ordering of the world becomes delirious. Critchley refers to this as a 'reversed intentionality' where, in novels like Thomas l'obscur, things like 'the sea, the night, words and language itself - regard us, where the Subject dissolves into its object' $(1997,58)$. Weariness is a feeling/mood that consumes the personhood of the one who undergoes it. Bonnet touches on a similar idea when he describes the occasions in Blanchot's work where the frontier between the 'personal and the prepersonal' begins to give way but he is wrong to describe this as an 'immersive relation to the world' (Bonnet 2016, 97) because what this reversed intentionality captures is a primal scene of disaster where there are no more 'subjects' to be immersed.

The question is, then, if one cannot undergo weariness in the domain of the possible how can one even speak of it? The implication is that writing is the residual affirmation of weariness and other limit-experiences like it. Writing is a voyage to the end of the possible; the turning of language away from its worldy referents (as in poetry and radical fiction) is undertaken at the expenditure of subjectivity. The need to write is linked to the approach toward this limit point. In other words, an irrepressible alterity - that exposes itself in various phenomenon such as the face of the Other, affliction, the cadaver, the night, weariness - is what creates the impulse to write; one glimpses, in these moments, a world other than ontological possibilities. Yet to write in response to alterity is to be excluded from writing; writing becomes radically impossible - an arena of personal exclusion for neutral affirmation. This fading of subjectivity results in writing being circular: there is no longer a subject to conceive of an entry point into writing and thus no longer a clear inaugural moment that calls one to write.

This vanishing point of the life that contains the 'point de vocation' that creates the need to write not only illuminates Blanchot's work as radical fiction but also illuminates Cascella as a contributor, via the sonorous, to this terrain. In his explanation of Blanchot, Fort defines the 'point de vocation' as those 'inaugural moments, violent and disruptive points that locate, however problematically, the initiation, confirmation, or affirmation of a vocation, and the decisive inflection of a trajectory located somewhere within life' $(2014,174-5)$. In short, it refers to the moment one decides to be a writer. What is significant about Blanchot's work is the way in which the event from which one decides to write loses itself to the impersonality of writing. With the forgetting of the inaugural moment comes the mysterious demand of writing, as if placed on the subject from a time and place beyond the now. For Blanchot, then, the beginning of writing is like the entry into a dream; just as there is no discernible point from which lived time passes into dream time, there is no discernible point from which the real time passes into the narrative. Likewise, as Cascella goes from listening (which is seemingly a 'point de vocation') into writing and back again, the sonorous becomes constituted by the trace that marks writing; a literary trace that forms the basis of a sonorous trace. Fundamentally, then, hers is a work of dispersion and absence where the sonorous is formed without agreement or law. It is a work of impossibility - much like Blanchot's own writing - not because it is conceptually impossible to answer to sound but because the type of writing she is engaged in is of a different order to possibility. It is not just the sonorous that is drawn toward absence but writing itself: she is a writer because something other than possibility has been revealed itself to her and at the same time it reveals itself to her because she is a writer.

\section{Reading as reverberation}


Both of Cascella's books (En Abîme and F.M.R.L.) are incomplete because the author who responds to a different order of language - like Blanchot and the poet - is unable to bring their task to an end. The persistence of the unnameable is fundamentally inexhaustible and therefore writing precedes and proceeds, as a work, the publication of any book. The type of writing that occupies the pages of Cascella and Blanchot's work never arrives at a point of consolidation or truth. A text occupied by traces can only advance by a movement of contestation and fragmentary encounters as approximations of the primordial murmur of the narrative voice. This is why writing sound is closer to radical fiction than the body of sound studies. In one respect Cascella's work offers itself as a union of the critical and creative but in another, more radical respect, it is writing as a limit-experience.

This type of writing calls for a very different type of reader than the interpreter or critic. Blanchot tells us how the critic's reading seeks to uncover hidden depths beneath apparent meaning in an essentially reductive fashion, attempting to draw what is irreducible in the text back to the 'profound forces, the sleeping archives, to the values rooted in our depths' (1999, 321). Reading that interests Blanchot, however, is always fascinated. The idea of fascination occurs when one's subjectivity is said to be drawn from itself by an alterity which remains 'free of determination' (Iyer 2005, 96). In fascination, seeing is no longer determined by what it sees but our gaze is swallowed by it, consumed to such a degree that the subject that is said to see is no longer a certainty. As a reversed intentionality, fascination serves as a reminder that the very constitution of subjectivity is determined by an excess over interiority which, as Blanchot writes, 'robs us of our power to give sense' $(1982,32)$. The fascinated reader thus enters into a relationship with the work not as an attempt uncover hidden depths but as a prolongation of 'the passion of writing' (Blanchot 1999, 318). Reading opens the work to further dispossession, robbing the author of his/her authority over the text and refusing meaning as a static location. Reading is what, in part, transforms the book into a work. Unlike the book, the work is not contested as something ill-disposed to meaning; as a work, the reader reads in solidarity with the intimacy of writing.

Cascella's writing is also deeply engaged as reading, both as an affixation of a kind of literary listening and as a displacement of her authority as author. The way she reads is discernibly fascinated; she does not read to unearth deep core meanings, reading grips her and draws her to amorphous approximations of the trace. This reading is in no way distinct from listening. In fact, the two activities are inseparable; sound and literary fragments bounce off one another in a writing called from the void. She describes this process as 'listeningreading-into-writing' (Cascella 2015, 24) where sound and the text are not fixed entities: 'listening and reading as activities in change and in time' (Cascella 2015, 28). She also reminds us how this process is circular, how writing feeds back into this very 'listeningreading'. Like Blanchot, Cascella reads in view of the void against writing that does not consolidate meaning. Her reading, then, further frustrates any closure of the work; her writing is not only her own approximations of the void but approximations drawn from her literary archive. And there is a strong sense in her writing that she knows this is how she will be read, as a reterritorialization on the part of the reader as further associations are made to singularities, ephemerality and approximations of the nothing.

This brings us to the closing point of the essay: reading in both Cascella and Blanchot's work should be understood as reverberation rather than resonance. Despite Cascella's claim that 'they [the words] point at resonances heard, early in life, in certain sounds, in a strong sense of kinship across time' $(2015,33)$ the reader is unable to rest in a simple self-identity. While on one hand Cascella wants to be read/heard through resonance which would, as Blanchot explains, constitute reading where we as the reader are 'sentimentally brought back to our own experience', the opening of writing to a different order of language in fact places the reader at the 'level of poetic power' which Blanchot explains is 
reading as reverberation. Reverberation does not consolidate anything close to sentimentality but is instead an 'instant summons to leave ourselves and to move in the shaking of its immobility' (Blanchot 1999, 321). What is radical and essential in Cascella's writing is not the call to be creative readers but fascinated readers in solidarity with the intimacy of writing as it constitutes a fundamental, poetic, dispossession.

The gap is the place of the tale

Cascella's work would be uninteresting if read at the surface level as another instalment in favour of sound's ephemerality. This is certainly a possibility if we read Cascella on the level of understanding, one that would constitute an epistemological myopia. But what this essay has shown is that Cascella's work must be read on the level of poetic power where 'the gap is the place of the tale' $(2015,80)$. Here her work aligns with Blanchot, and writing sound with radical fiction, as a reflexive practice of intimacy constituted by a vanishing point where the world and the subject who inhabits it is fundamentally dispossessed. This writing is occupied by an endless series of traces and prolonged by reading as reverberation. On this level, her work is a work of impossibility where listening, reading and writing are fundamentally anarchic.

\footnotetext{
${ }^{1}$ It is important to remember that Blanchot has very specific authors in mind when he speaks of poetry. This is also true of his reference to literature. The poetry and literature that grips Blanchot's texts is invested in that point of impossibility of language and the vanishing point of authorship. Kafka, Rilke, Mallarmé, Beckett, Hölderlin, Breton (to name a few) a regular reference points in Blanchot's work.
} 
Reference List

Blanchot, Maurice. 1955/1982. The Space of Literature. Trans. Ann Smock. London: University of Nebraska Press.

Blanchot, Maurice. 1969/1999. The Infinite Conversation. Trans. Susan Hanson. Minnesota, MN: Univ. of Minnesota Press.

Blanchot, Maurice. 1943/2001. Faux Pas. Trans. Charlotte Mandel. Stanford, CA: Stanford Univ, Press.

Blanchot, Maurice. 1959/2003. The Book to Come. Trans. Charlotte Mandell. Stanford, CA: Stanford Univ. Press.

Bonnet, François, J. 2016. The Order of Sounds: A Sonorous Archipelago. Trans. Robin Mackay. Falmouth: Urbanomic.

Bruns, Gerald. 2011. On Ceasing to be Human. Standfor, CA: Stanford Univ. Press.

Cascella, Daniela. 2012. En Abîme: Listening, Reading, Writing. Winchester; Washington: Zero Books.

Cascella, Daniela. 2015. F.M.R.L.: Footnotes, Mirages, Refrains and Leftovers of Writing Sound. Winchester; Washington: Zero Books.

Critchley, Simon. 1997. Very Little...Almost Nothing: Death, Philosophy and Literature. London: Routledge.

Derrida, Jacques. 1973/1982. 'Différance'. In Margins of Philosophy. Trans. Alan Bass. Chicago: Chicago Univ. Press.

Fort, Jeff. 2014. The Imperative to Write: Destitutions of the Sublime in Kafka, Blanchot and Beckett. Bronx, NY: Fordham Univ. Press.

Iyer, Lars. 2005. Blanchot's Vigilance: Literature, Phenomenology and the Ethical. Hampshire: Palgrave Macmillan.

Large, William. 2004. Emmanuel Levinas and Maurice Blanchot: Ethics and the Ambiguity of Writing. Manchester: Clinamen Press.

Meillassoux, Quentin. 2009. After Finitude: An Essay on the Necessity of Contingency. London; New York: Continuum.

Nancy, Jean-Luc. 1993. The Birth of Presence. Trans. Claudette Sartiliot. Stanford, CA: Stanford Univ. Press. 
Schrimshaw, Will. 2016. 'Exit Immersion'. Sound Studies: An Interdisciplinary Journal. 1 (1): 155170. DOI: 10.1080/20551940.2015.1079982.

Stern, Jonathan. 2003. The Audible Past: Cultural Origins of Sound Reproduction. London: Duke Univ. Press.

Voegelin, Salomé. 2010. Listening to Noise and Silence: Towards a Philosophy of Sound Art. London; New York: Continuum. 